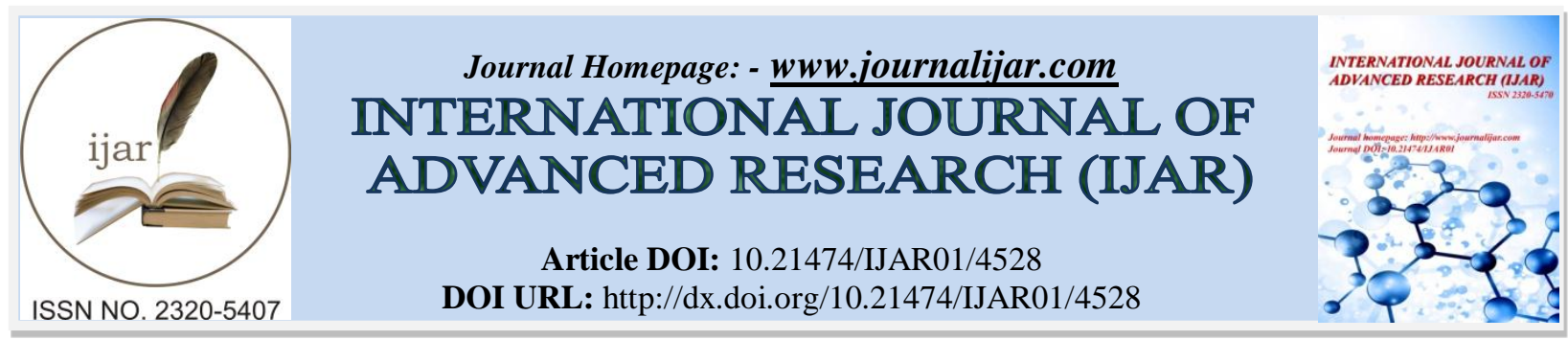

RESEARCH ARTICLE

\title{
A COMPARATIVE MICROBIAL QUALITY ASSESSMENT OF FRESH SEAFOODS COLLECTED FROM WHOLESALE AND RETAIL MARKETS IN EASTERN PROVINCE OF SAUDI ARABIA.
}

\begin{abstract}
"Mohamed Ibrahim, M.A., Sami Shabeeb Al Shabeeb, Nabil Bin Ibrahim Fita and Ghamri H. Al Ramadhan. Fisheries Research Center, Deputy Ministry for Fisheries, Ministry of Environment, Water \& Agriculture, Kingdom of Saudi Arabia.
\end{abstract}

\section{Manuscript Info}

Manuscript History

Received: 19 April 2017

Final Accepted: 21 May 2017

Published: June 2017

Key words:-

Microbial Quality, Seafoods, TPC, TCC,

Sanitation, Pathogens

\begin{abstract}
A study was conducted to comparatively evaluate the microbial quality of seafoods collected from fish markets in Eastern Province of Saudi Arabia during the period from January 2015 until May 2016. In this study, Fishes, Prawn and Cuttlefish samples were analysed in 2 sampling categories such as samples collected from wholesale fish market (200 samples) and retail fish markets (200 samples). Total Plate Count (TPC) and Total Coliforms Count (TCC) in the skin attached muscles were analysed using Plate Count Agar (PCA) and Violet Red Bile Agar (VRBA), respectively. The mean Total Plate Count of bacteria and mean Total Coliform Count detected in all the raw seafood samples collected from retail markets were comparatively higher than that of seafood samples collected from wholesale markets as per the limits of SASO. From the result it can be concluded that most of the seafoods sold in the retail markets are not met the standards for human consumption. Thus, it is strongly recommended to enhance proper controlling of the storage and shelf life of the seafoods by implementing preventive measures and application of sanitation procedures in the fish markets to monitor the quality of raw seafoods by reducing the prevalence of the pathogens.
\end{abstract}

Copy Right, IJAR, 2017,. All rights reserved.

\section{Introduction:-}

The Kingdom of Saudi Arabia on the Arabian Peninsula is encircled by water, with the Arabian Sea to the southeast and the Red Sea to the west. Though fish is not really a staple of the Saudi diet, demand for fresh fish is growing. Annual fish consumption per capita raised from three kilograms in 1977 to 6.5 kilograms in 1998. Fish may be a major source of protein and its harvesting, handling, process and distribution offer livelihood for millions of people. It is the most important animal protein food available in the tropics, and it represents about $14 \%$ of all animal protein on a global basis (Abolagba and Melle, 2008; Lin Ming-hsien).

Fish may be Finfish, Shellfish (molluscs and crustaceans), or any other sort of marine or freshwater animal life that may be used for human or domestic animal consumption (Mahmuda et al, 2010). Fish and seafood products represent a crucial food material in the international trade due to its ever escalating consumption demand. Fish partakes about $60 \%$ of the world supply of protein, and $60 \%$ of the developing world bring forth more than $30 \%$ of their animal protein from fish (Emikpe et al, 2011). Fish is a crucial part of a healthy diet due to its top quality

Corresponding Author:- Mohamed Ibrahim.

Address:- Fisheries Research Center, Deputy Ministry for Fisheries, Ministry of Environment, Water \& 1227 
protein, other important nutrients and omega 3-fatty acids, and its low fat content as compared to different meats (Rhea, 2009; Pal, 2010).

The microbiological flora within the intestines of seafoods like finfish, shellfish, and cephalopods is sort of totally different being psychotrophic in nature and to some proportions believed to be a reflection of the general contamination within the aquatic surroundings (Adebayo-Tayo et al, 2012). Pathogenic bacteria related with fish and fishery products can be classified in to three common groups: (1) Bacteria (indigenous) that belong to the natural microflora of fish (2) Enteric bacteria (non-indigenous) that are introduced as a result of fecal contamination, (3) Bacterial contamination during processing, storage or preparation for consumption (Lyhs, 2009).

Fish, due to their soft tissues and aquatic biosphere are immensely prone to microbial contamination. Numbers of bacteria, most of them potential spoilers, are present in the surface slime, on the gills and within the intestines of live fish, although the flesh itself is often sterile. Bacterial growth and invasion on the fish are prevented by the body's natural defence system throughout life however when death occurs the defence system breaks down and the bacteria multiply and invade the flesh. And also immediately fish dies, it continues to exist in top quality just for a short while. However, spoilage soon sets in which is occasioned by elevation in the ambient temperature that provoke favourable conditions for microorganisms to strive (Clucas and Ward, 1996).

Fishery products have been recognized as a major carrier of food-borne pathogens. The contamination may occur before harvest, throughout harvest and processing operations, distribution, storage and preparation of the product. In a simplified overview, poor quality products, spoiled or decomposed are infrequently liable for food poisoning since they are generally disposed before consumption. Food poisoning in seafood products such as scombroid or histamine poisoning, generally is the consequence of mishandling during or after preparation. The microbial flora of seafood is connected to the environment, from which the fish are harvested (Wekell et al, 1994; Falana, 2003).

The quality of fish might be degraded through a complex process, during which the microbiological forms of deterioration are involved. The enzymatic and chemical reactions are typically responsible for the preliminary loss of freshness whereas microbial proceedings are responsible for the definite spoilage, and thereby establish product shelf life. Thus, the requirement for control of quality of the seafoods to abstain excessive microbial contamination, which may lead to antibiotics resistance, is well described, and since the rate of seafood borne diseases is elevating, there is an urgent means of assuring quality of sea food (Huss, 1997; Adebayo-Tayo et al, 2012).

The count of Coliforms which belongs to the family of Enterobacteriaceae is considered as an index to ascertain the seafood quality. Several human pathogens such as Escherichia coli, Klebsiella sp, Salmonella sp, Citrobacter sp and Proteus sp, when isolated from fish and fish products gives an identification about environmental fecal contamination of fish. These organisms have been found to sustain and proliferate in the gut, mucus and tissues of fish and that contribute fish acting as potential carrier of human illness over long time (Onyango et al, 2009; Wogu and Maduakol, 2010).

Austin and Austin (1996), have denoted the existence of pathogenic enterobacteria comprising coliforms in fish that lives in contaminated marine water by domestic wastewater, such as: Escherichia coli, Enterobacter cloacae, Citrobacter sp., S paratyphi A and B, S. enteritidis, S. Amsterdam, P. vulgaris, P. rettgeri, Proteus mirabilis, Proteus morganii, Clostridium botulinum, C group Enterobacter, Streptococcus faecalis and Strptococcus faecium. Foodborne microbiologic hazards may be accountable for as several cases of illness as possible each year and are thus a crucial food safety challenge. To reduce the prevalence of foodborne disease, many specialists and stakeholders propel the development of a science- and risk-based food safety system, in which decision makers emphasize hazards and interventions using the best accessible data on the dispensation and decrement of risks (Batz et al, 2005).

The aim of microbiological examinations of seafoods is to assess the possible presence of organisms of public health importance and to give an impression of the hygienic quality of the fish including temperature abuse and hygiene during handling and processing. Regarding to the potential public health threat that the seafood may constitute, the main purpose of this study was to determine and evaluate the microbial contamination of seafood products collected from wholesale and retail fish markets in Eastern Province of Saudi Arabia. 


\section{Materials and Methods:- \\ Sample collection:-}

Totally 400 fresh seafood samples comprising of Fishes, Prawn and Cuttlefish were collected from the wholesale (200 samples) and retail shops (200 samples) in fish markets in Eastern Province of Saudi Arabia during the period from January 2015 until May 2016. In this study thirty two species of fishes were selected for the analysis of microbial loads along with common cuttlefish and Prawns. The details of examined seafood samples were shown in Table 1. Samples were collected and kept in sterile polyethylene bags embedded with ice and transported rapidly to the laboratory in an insulated box. The time gap between the collection of samples and analysis was approximately 1 hour.

\section{Preparation of Samples:-}

This was done by cutting $50 \mathrm{~g}$ of skin attached muscles with sterile scalpel and is mixed in $450 \mathrm{ml}$ of sterile physiological saline in a filter stomacher bag and made in to slurry using the BagMixer ${ }^{\circledR}$ (Interscience, France). The resulting solution represent a dilution stage of $10^{-1}, 10^{-2}, 10^{-3}$ and $10^{-4}$ were prepared by transferring $10 \mathrm{ml}$ of the previous dilution in to $90 \mathrm{ml}$ of sterile physiological saline and so on. Mixing of the sample at each dilution was also done by rotating and shaking vigorously, so as to resuspend the material uniformly.

Inoculation of plates for enumeration of bacterial load:-

All media used in the present study were from Oxoid, U.K. and prepared according to the standard procedure. Media were sterilized by autoclaving at $121^{\circ} \mathrm{C}$ at 15 psi pressure for 15 minutes, unless otherwise specified. Sterility of the media was checked by incubating at $37^{\circ} \mathrm{C}$ for 24 hours. The microbiological analysis was performed as per the standard methods adopted from Online Bacteriological Analytical Manual, USFDA, (BAM $8^{\text {th }}$ edition Online).

Total Plate Count (TPC):-

$50 \mathrm{~g}$ of the sample were homogenized in $450 \mathrm{ml}$ of sterile physiological saline as mentioned in the sample preparation procedure. After serial dilution up to fourth dilution, the samples were pour-plated on Plate Count Agar (PCA). The colonies were counted after 48 hours of incubation of the plates at $37^{\circ} \mathrm{C}$.

\section{Total Coliform Count (TCC):-}

Dilutions made for the Total Plate Count were plated on Violet Red Bile Agar (VRBA); typical Purple colonies surrounded by a purple zone were counted after 24 hours of incubation of the plates at $37^{\circ} \mathrm{C}$.

\section{Statistical Analysis:-}

The results of the present study were tabulated and statistical analyses were conducted using the software: Statistical Package of the Social Sciences (SPSS) version 22.

\section{Results:-}

The results of the range of Total Plate Count (TPC) of bacteria on the Plate Count Agar and Total Coliforms Count on the Violet Red Bile Agar for the seafood samples collected from both wholesale and retail fish markets are shown in Table 2 and Table 3 respectively. Mean Total Plate Count and Total Coliform Count for examined seafood samples collected from both wholesale and retail fish markets are presented in Table 4. In the wholesale market, the highest number of bacterial count was obtained from Prawn samples which were $1.47 \pm 1.06 \times 10^{5} \mathrm{CFU} / \mathrm{g}$, followed by Fishes with the count of $1.31 \pm 6.36 \times 10^{4} \mathrm{CFU} / \mathrm{g}$, while the least count of $8.95 \pm 6.75 \times 10^{3} \mathrm{CFU} / \mathrm{g}$ was obtained from Cuttlefish samples. Whereas, the results obtained for the mean Total Plate Count of seafood samples collected from retail markets ranged from $3.53 \pm 8.20 \times 10^{6} \mathrm{CFU} / \mathrm{g}$ for prawn, followed by Cuttlefish with the count of $1.10 \pm$ $2.09 \times 10^{6} \mathrm{CFU} / \mathrm{g}$ and the least count of $1.74 \pm 4.68 \times 10^{5} \mathrm{CFU} / \mathrm{g}$ was obtained from the fishes. Also, Table 4 showed the result obtained for the mean Total Coliform Count of seafood samples collected from both wholesale and retail fish markets. In the wholesale market, the highest number of Coliform count was obtained from Prawn sample which was $7.36 \pm 9.72 \times 10^{3} \mathrm{CFU} / \mathrm{g}$, followed by fishes with the count of $5.14 \pm 2.40 \times 10^{2} \mathrm{CFU} / \mathrm{g}$, while the least count of $1.40 \pm 1.56 \times 10^{2} \mathrm{CFU} / \mathrm{g}$ was obtained from Cuttlefish samples. Similarly, the results obtained for the mean Total Coliform Count of seafood samples collected from retail markets ranged from $1.21 \pm 1.44 \times 10^{4} \mathrm{CFU} / \mathrm{g}$ for Prawn, followed by Cuttlefish with the count of $8.32 \pm 1.40 \times 10^{3} \mathrm{CFU} / \mathrm{g}$ and the least count of $1.69 \pm 3.04 \times 10^{3}$ $\mathrm{CFU} / \mathrm{g}$ was obtained from the fishes. 


\section{Discussion:-}

Fish is very important foodstuff in developing countries because of its high protein content, and nutritional value. Fish provides over 50\% of the animal protein for the populations of 34 countries (Pal, 2010). Spoilage is outlined as a modification in fish or fish products that disrupts it less acceptable, unacceptable or unsafe for human consumption. The contamination usually takes place from human and animal origin, and thus, fish and seafood can be associated in the transmission of pathogenic microorganisms and toxins (Pal, 2012). In this present study, three types of seafoods comprising of Fishes, Prawn and Cuttlefish were analysed in two sampling categories (wholesale and retail markets) to comparatively evaluate their microbial quality; the mean Total Plate Count (TPC) of bacteria gave the following $1.31 \pm 6.36 \times 10^{4} \mathrm{CFU} / \mathrm{g}, 1.47 \pm 1.06 \times 10^{5} \mathrm{CFU} / \mathrm{g}, 8.95 \pm 6.75 \times 10^{3} \mathrm{CFU} / \mathrm{g}$ for Fishes, Prawn and Cuttlefish respectively, collected from wholesale markets in Eastern Province of Saudi Arabia. Whereas, the mean Total Plate Count (TPC) of bacteria for the samples collected from retail markets gave the following $1.74 \pm$ $4.68 \times 10^{5} \mathrm{CFU} / \mathrm{g}, 3.53 \pm 8.20 \times 10^{6} \mathrm{CFU} / \mathrm{g}, 1.10 \pm 2.09 \times 10^{6} \mathrm{CFU} / \mathrm{g}$ for Fishes, Prawn and Cuttlefish samples respectively. SASO specifies the upper (Rejectable) and lower (Marginal) levels of acceptability as for TPC as $1.0 \mathrm{x}$ $10^{7} \mathrm{CFU} / \mathrm{g}$ and $5.0 \times 10^{5} \mathrm{CFU} / \mathrm{g}$ respectively. Similar results were noticed by Reza et al., in 2009 for Silver Jewfish, Bombay duck, big eye Tuna, Chinese Pomfret and Ribbon Fish. In their investigation, TPC ranged between $1.1 \mathrm{x}$ $10^{5} \mathrm{CFU} / \mathrm{g}$ to $6.7 \times 10^{4} \mathrm{CFU} / \mathrm{g}$. Moreover, comparable findings have also been observed in Hilsha as $1.6 \times 10^{5}$ CFU/g by Salim in 2005; in shrimp as $1.3 \times 10^{6}$ to $3.0 \times 10^{6} \mathrm{CFU} / \mathrm{g}$ by Janice and Lee in 1968 . According to the TPC value, the Fishes, Prawn and Cuttlefish samples which were collected from the wholesale markets are within the permissible range as per the limits of SASO. Whereas, the TPC values of Fishes collected from the retail markets are only within the permissible range, but the Prawn and Cuttlefish samples which have the count that exceeds the marginal levels of acceptability and were not fit for human consumption. The density of Total Plate Count of bacteria detected in all the raw seafood samples collected from retail markets were comparatively higher than that of seafood samples collected from wholesale markets. A huge population of bacteria in food indicates the overall quality of the food and therefore the degree of spoilage it would have undergone. The incidence of total bacterial counts of various samples examined from retail markets having high ranges of bacterial count that lift up the concern about the hygienic condition of the production and point of sale environment. However, the greatest risk to human health is due to the consumption of raw or insufficiently processed fish and fish products (Yagoub, 2009). Moreover, the product is stored for relatively long period until sold and sometimes storage circumstances cannot be ensured properly due to technological faults (Clem and Garett, 1968). Preservation in low quality ice, handling with contaminated hands could also be liable for increased density of aerobic bacteria. Fish are very much prone to contamination with various bacteria because of their perishable protein content (Shankar et al, 2009). Other potential sources of microbial contaminations are the equipment used for each operation that is performed until the final product is eaten; the clothing and hands of personnel and the physical establishments themselves are all involved (Rombouts and Nout, 1994). Apart from the microorganisms that fishes have at the time of capture, more is added through unhygienic applications and contaminated equipment such as storage stations. This was revealed by studies that compared the quality and storage life of completely aseptically treated fish (aseptic handling), washed fish, iced in cleansed plastic boxes, with clean ice (clean handling) and with un-washed fish, iced in old, dirty wooden boxes (normal handling). A significant difference was found in the bacterial contamination of the three batches, the latter excessively contaminated with a decrement in storage life compared with the other samples (Huss et al, 1974). The layout of a fish hold is of great importance as far as hygiene in the hold is concerned. Hold design should allow the dismissal to be collected easily. The amount of dismissal was proposed to be elevated at $5-7^{\circ} \mathrm{C}$; at which temperature there is considerable spoilage since the dismissal is a very good medium for bacterial growth (Hermansen et al, 1983). Foods in exposure with contaminated surfaces may have their microbiological quality weakened, principally if they're ingested raw or if the heat treatment is not sufficient for inactivating vegetative cells or bacterial toxins that might be available (Temelli et al, 2006; Jha et al, 2010). Bad hygienization operations of surfaces that make exposure with fish throughout all production levels are also a important factor for the quality of the final product. Some researchers have denoted elevated prevalence of microorganisms in appliances and utensils in food-processing sectors caused by failures in engaging appropriate hygienization methods, which concludes in serious public health or economic issues (Consuelo et al, 2014).

The Coliforms which belongs to the family of Enterobacteriaceae are all arising on fish products as a consequence of contamination from the animal/human origin. This contamination has generally been connected with fecal contamination or pollution of natural water or water environments, where these organisms may persist for a long time (months) or through direct contamination of products during processing. In this present study, the mean Total Coliforms Count (TCC) gave the following, $5.14 \pm 2.40 \times 10^{2} \mathrm{CFU} / \mathrm{g}, 7.36 \pm 9.72 \times 10^{3} \mathrm{CFU} / \mathrm{g}$ and $1.40 \pm 1.56 \mathrm{x}$ $10^{2} \mathrm{CFU} / \mathrm{g}$ for Fishes, Prawn and Cuttlefish samples respectively, collected from wholesale markets in Eastern 
Province of Saudi Arabia. Whereas, the mean Total Coliform Count (TCC) for the samples collected from retail markets gave the following, $1.69 \pm 3.04 \times 10^{3} \mathrm{CFU} / \mathrm{g}, 1.21 \pm 1.44 \times 10^{4} \mathrm{CFU} / \mathrm{g}$ and $8.32 \pm 1.40 \times 10^{3} \mathrm{CFU} / \mathrm{g}$ for Fishes, Prawn and Cuttlefish samples respectively. According to ICMSF, Total Coliforms limits, $1.0 \mathrm{x} 10^{2} \mathrm{CFU} / \mathrm{g}$ can be present in the food. But all the Fishes, Prawns and Cuttlefish samples analysed which were collected from both wholesale and retail markets were exceeding the limit. But, the density of Total Coliforms Count detected in all the raw seafood samples collected from retail markets were comparatively higher than that of seafood samples collected from wholesale markets. Coliforms which belong to the family of Enterobacteriaceae are very useful as indicators of poor hygiene and their existence in huge population indicates a big likelihood of their proliferation and implying multiplication of other pathogens (Nissen et al, 2001). Their existence in fish reveals the level of pollution of their environment because Coliforms are not the normal of bacteria in fish. Coliforms such as E.coli are generally found where there has been faecal contamination from warm blooded animals (Chao et al, 2003). The presence of coliform group in elevated level, suggests contamination of the samples before or during handling, processing and marketing. The excess density of Coliforms in fish body may be due to secondary contamination while handling and storage. Huge quantities of coliform bacteria in water and fish are not pathogenic to human, but may indicate a higher risk of pathogens being present. Dysentery, typhoid fever, bacterial gastroenteritis and much other water borne disease may occur simultaneously with faecal coliform contamination. The presence of faecal coliform may affect humans more than it does aquatic organisms (Doyle and Ericson, 2006). The isolation of these groups of organisms specify faecal and environmental pollution and these supported the findings of Yagoub et al (2004). This also confirms the findings of Koutsoumanis and Nychas (2000), Gonzalez (2004) and Herrera et al (2006); who isolated similar organisms from fish and fish products. Allen (1979) have stated that most of the epidemics characteristic to wastewater sources are from raw sewage obtaining access to food eaten directly by man, or from contamination of water supply systems by untreated sewage. Olayemi et al (1991) have reported that the existence of faecal coliform in fish intended for human consumption may bring forth a potential danger not only in causing disease, but also because of the possible transfer of antibiotic resistance from aquatic bacteria to human infecting bacteria from nonaquatic sources. Priyanka Rani Majumdar et al (2014), stated that the untreated and the improper way of sewage disposal system in the water body is one of the principal sources for microbial water contamination which results in the accumulation of these bacterial pathogenic species in the commercial edible fishes. Moreover, unhygienic handling by infected people or healthy carriers, during the capture, transport and processing may also act as a source of contamination by pathogenic organisms in seafoods.

\section{Conclusion:-}

Fishes are very much prone to contamination with various bacteria because of their highly perishable protein content in their body. This study gives a clear approach on the difference of bacterial load comparatively in seafood samples collected from wholesale and retail fish markets in Eastern Province of Saudi Arabia. The study also revealed that the microbiological state of samples collected from wholesale market was less contaminated than the samples collected from retail markets due to the airtight display tray with sufficient ice and careful handling. Besides this, some collected samples from retail markets were more contaminated. The fact is that the product is stored for relatively long period until sold and sometimes storage circumstances cannot be ascertained properly due to inadequate icing and technological disruption. From the result, it can be concluded that the fish sold in the retail markets are not standard to consume since the observed microbial levels are always higher than the recommended levels. To overcome this situation, it is obligatory to follow the code of practice concerning handling of the catch, icing, post-harvesting strategies and storage including depuration and hygienic measures. Appropriate hygienic condition should be maintained at every step of catching, landing and transportation, processing and marketing following HACCP steps for good quality of fish and fishery products.

\section{Acknowledgements:-}

Sincere thanks to Municipality officers, workers and vendors of Dammam Fish Market for their kind support during sampling for this study.

Table 1:- Details of Examined Seafood samples*

\begin{tabular}{|l|l|l|l|}
\hline S. No & SCIENTIFIC NAME & ENGLISH NAME & LOCAL NAME \\
\hline 01. & Argyrops spinifer & Long-spined Bream & Andak \\
\hline 02. & Lethrinus nebulosus & Spangled Emperor & Shaour \\
\hline 03. & Epinephelus chlorostigma & Brown-spotted Grouper & Hamour \\
\hline 04. & Acanthopagrus bifasciatus & Double-bar Bream & Faskar \\
\hline
\end{tabular}




\begin{tabular}{|l|l|l|l|}
\hline 05. & Seriola dumerili & Greater Amberjack & Hamam \\
\hline 06. & Siganus canaliculatus & Rabbit Fish & Safi \\
\hline 07. & Acanthopagrus berda & Black Bream & Sha'am \\
\hline 08. & Diagramma pictum & Painted Sweetlips & Sekhal \\
\hline 09. & Scomberomorous cavalla & King Mackerel & Kana'ad \\
\hline 10. & Liza subviridis & Mullet & Mullet \\
\hline 11. & Lutjanus madras & Indian Snapper & Nae'sar \\
\hline 12. & Sphyraena jello & Pickhandle Barracuda & Jidd \\
\hline 13. & Gnathanodon speciosus & Golden Trevally & Rabib \\
\hline 14. & Cephalopholis hemistiktos & Half-spotted Grouper & Najil \\
\hline 15. & Nemipterus japonicas & Threadfin Bream & Bassij \\
\hline 16. & Platax pinnatus & Dusky Batfish & Imad \\
\hline 17. & Lutjanus malabaricus & Malabar Blood Snapper & Hamrah \\
\hline 18. & Euthynnus affinis & Eastern Little Tuna & Sharwa \\
\hline 19. & Seriolina nigrofasciata & Black-banded Trevally & Hamam Arabi \\
\hline 20. & Rhabdosagrus haffara & Haffara Bream & Gorgofan \\
\hline 21. & Gerres acinaces & Longtail Silverbiddy & Badah \\
\hline 22. & Rastrelliger kanagurta & Indian Mackerel & Bagha \\
\hline 23. & Scromberoides commersonnianus & Large-mouth Queenfish & Lehlah \\
\hline 24. & Platycephalus indicus & Bartail Flathead & Wahhar \\
\hline 25. & Rachycentron canadum & Cobia & Sikkin \\
\hline 26. & Ablennes hians & Needle Fish & Hakool \\
\hline 27. & Pinjalo pinjalo & Pinjalo Snapper & Naimi \\
\hline 28. & Carcharinus macloti & Hardnose Shark & Jarjur \\
\hline 29. & Saurida tumbil & Greater Lizardfish & Macarona \\
\hline 30. & Trichiurus lepturus & Ribbon Fish & Khardawil \\
\hline 31. & Pseudorhombus arsius & Largetooth Flounder & Musa \\
\hline 32. & Alepes djedaba & Shrimp Scad & Jinnis \\
\hline 33. & Penaeus indicus & Prawn & Rubyan \\
\hline 34. & Sepia sp. & Cuttlefish & Khattak \\
\hline & & \\
\hline & (1986) a That (1995) & \\
\hline
\end{tabular}

*Wajeeha (1986) and Thabit (1995)

Table 2:- Range of Total Plate Count (TPC) CFU/g \& Total Coliform Count (TCC) CFU/g in the examined samples collected from Wholesale Market

\begin{tabular}{|l|l|l|l|l|}
\hline S. No & FISH NAME & No. OF SAMPLES & $\begin{array}{l}\text { TPC } \\
\text { MEAN } \pm \text { S.D }\end{array}$ & $\begin{array}{l}\text { COLIFORMS } \\
\text { MEAN } \pm \text { S.D }\end{array}$ \\
\hline 01. & Long-spined Bream & 13 & $6.36 \pm 1.68 \times 10^{3}$ & $1.66 \pm 5.55 \times 10^{3}$ \\
\hline 02. & Spangled Emperor & 12 & $7.35 \pm 1.31 \times 10^{3}$ & $1.96 \pm 3.33 \times 10^{2}$ \\
\hline 03. & Brown-spotted Grouper & 10 & $1.03 \pm 1.55 \times 10^{3}$ & $2.40 \pm 3.59 \times 10^{1}$ \\
\hline 04. & Double-bar Bream & 10 & $2.21 \pm 3.33 \times 10^{3}$ & $6.20 \pm 6.98 \times 10^{1}$ \\
\hline 05. & Greater Amberjack & 10 & $1.36 \pm 2.69 \times 10^{4}$ & $8.34 \pm 2.29 \times 10^{2}$ \\
\hline 06. & Rabbit Fish & 08 & $4.65 \pm 5.82 \times 10^{3}$ & $1.58 \pm 1.69 \times 10^{2}$ \\
\hline 07. & Black Bream & 07 & $2.00 \pm 2.76 \times 10^{3}$ & $8.00 \pm 1.20 \times 10^{1}$ \\
\hline 08. & Painted Sweetlips & 07 & $4.28 \pm 1.05 \times 10^{4}$ & $9.95 \pm 2.45 \times 10^{2}$ \\
\hline 09. & King Mackerel & 06 & $3.63 \pm 3.32 \times 10^{3}$ & $1.51 \pm 1.89 \times 10^{2}$ \\
\hline 10. & Mullet & 05 & $6.60 \pm 6.54 \times 10^{2}$ & $1.90 \pm 2.13 \times 10^{2}$ \\
\hline 11. & Indian Snapper & 05 & $1.28 \pm 1.05 \times 10^{3}$ & $6.20 \pm 4.91 \times 10^{1}$ \\
\hline 12. & Pickhandle Barracuda & 05 & $1.60 \pm 3.14 \times 10^{5}$ & $4.14 \pm 8.86 \times 10^{3}$ \\
\hline 13. & Golden Trevally & 05 & $1.46 \pm 1.61 \times 10^{3}$ & $2.48 \pm 2.20 \times 10^{2}$ \\
\hline 14. & Half-spotted Grouper & 05 & $1.32 \pm 1.54 \times 10^{3}$ & $1.88 \pm 1.77 \times 10^{2}$ \\
\hline 15. & Threadfin Bream & 04 & $3.50 \pm 4.72 \times 10^{2}$ & $5.00 \pm 1.00 \times 10^{2}$ \\
\hline 16. & Dusky Batfish & 04 & $9.37 \pm 1.38 \times 10^{3}$ & $2.12 \pm 1.59 \times 10^{2}$ \\
\hline 17. & Malabar Blood Snapper & 03 & $6.33 \pm 4.93 \times 10^{3}$ & $9.00 \pm 9.84 \times 10^{1}$ \\
\hline 18. & Eastern Little Tuna & 03 & $6.00 \pm 1.03 \times 10^{3}$ & $2.66 \pm 4.61 \times 10^{1}$ \\
\hline
\end{tabular}




\begin{tabular}{|l|l|l|l|l|}
\hline 19. & Black-banded Trevally & 03 & $3.33 \pm 3.21 \times 10^{3}$ & $1.00 \pm 1.73 \times 10^{2}$ \\
\hline 20. & Haffara Bream & 03 & $2.16 \pm 2.46 \times 10^{3}$ & $9.66 \pm 8.96 \times 10^{1}$ \\
\hline 21. & Longtail Silverbiddy & 03 & $2.66 \pm 3.51 \times 10^{4}$ & $2.66 \pm 2.30 \times 10^{2}$ \\
\hline 22. & Indian Mackerel & 03 & $8.46 \pm 1.02 \times 10^{3}$ & $6.36 \pm 1.00 \times 10^{2}$ \\
\hline 23. & Large-mouth Queenfish & 03 & $6.00 \pm 5.19 \times 10^{3}$ & $4.96 \pm 7.82 \times 10^{2}$ \\
\hline 24. & Bartail Flathead & 02 & $7.55 \pm 1.05 \times 10^{4}$ & $3.25 \pm 1.76 \times 10^{2}$ \\
\hline 25. & Cobia & 02 & $1.42 \pm 1.95 \times 10^{4}$ & $2.60 \pm 3.39 \times 10^{2}$ \\
\hline 26. & Needle Fish & 02 & $1.25 \pm 1.06 \times 10^{3}$ & $1.15 \pm 1.20 \times 10^{2}$ \\
\hline 27. & Pinjalo Snapper & 02 & $1.25 \pm 1.06 \times 10^{3}$ & $5.50 \pm 6.36 \times 10^{1}$ \\
\hline 28. & Hardnose Shark & 02 & $6.00 \pm 5.65 \times 10^{2}$ & $3.00 \pm 2.82 \times 10^{1}$ \\
\hline 29. & Greater Lizardfish & 02 & $2.90 \pm 3.53 \times 10^{4}$ & $2.45 \pm 7.77 \times 10^{2}$ \\
\hline 30. & Ribbon Fish & 02 & $7.50 \pm 3.53 \times 10^{2}$ & $1.05 \pm 1.34 \times 10^{2}$ \\
\hline 31. & Largetooth Flounder & 02 & $1.25 \pm 1.34 \times 10^{4}$ & $2.06 \pm 2.74 \times 10^{3}$ \\
\hline 32. & Shrimp Scad & 02 & $9.00 \pm 4.24 \times 10^{3}$ & $6.50 \pm 4.94 \times 10^{1}$ \\
\hline 33. & Prawn & 23 & $1.47 \pm 1.06 \times 10^{5}$ & $7.36 \pm 9.72 \times 10^{3}$ \\
\hline 34. & Cuttlefish & 22 & $8.95 \pm 6.75 \times 10^{3}$ & $1.40 \pm 1.56 \times 10^{2}$ \\
\hline
\end{tabular}

Table 3:- Range of Total Plate Count (TPC) CFU/g \& Total Coliform Count (TCC) CFU/g in the examined samples collected from Retail Market

\begin{tabular}{|c|c|c|c|c|}
\hline S. No & FISH NAME & No. OF SAMPLES & $\begin{array}{l}\text { TPC } \\
\text { MEAN } \pm \text { S.D }\end{array}$ & $\begin{array}{l}\text { COLIFORMS } \\
\text { MEAN } \pm \text { S.D }\end{array}$ \\
\hline 01. & Long-spined Bream & 13 & $2.19 \pm 3.28 \times 10^{5}$ & $1.98 \pm 2.89 \times 10^{3}$ \\
\hline 02. & Spangled Emperor & 12 & $7.45 \pm 3.61 \times 10^{4}$ & $9.67 \pm 1.06 \times 10^{2}$ \\
\hline 03. & Brown-spotted Grouper & 10 & $5.17 \pm 1.38 \times 10^{5}$ & $6.40 \pm 1.18 \times 10^{2}$ \\
\hline 04. & Double-bar Bream & 10 & $7.40 \pm 5.13 \times 10^{4}$ & $1.81 \pm 2.51 \times 10^{3}$ \\
\hline 05. & Greater Amberjack & 10 & $5.47 \pm 3.48 \times 10^{4}$ & $4.03 \pm 2.92 \times 10^{2}$ \\
\hline 06. & Rabbit Fish & 08 & $8.87 \pm 1.36 \times 10^{3}$ & $6.88 \pm 1.47 \times 10^{2}$ \\
\hline 07. & Black Bream & 07 & $1.22 \pm 1.38 \times 10^{5}$ & $4.37 \pm 6.08 \times 10^{3}$ \\
\hline 08. & Painted Sweetlips & 07 & $1.23 \pm 1.41 \times 10^{5}$ & $5.00 \pm 8.52 \times 10^{2}$ \\
\hline 09. & King Mackerel & 06 & $7.33 \pm 1.18 \times 10^{4}$ & $8.03 \pm 1.42 \times 10^{2}$ \\
\hline 10. & Mullet & 05 & $1.05 \pm 7.40 \times 10^{5}$ & $1.45 \pm 1.59 \times 10^{3}$ \\
\hline 11. & Indian Snapper & 05 & $3.46 \pm 6.14 \times 10^{5}$ & $8.40 \pm 1.14 \times 10^{2}$ \\
\hline 12. & Pickhandle Barracuda & 05 & $2.07 \pm 2.46 \times 10^{5}$ & $3.80 \pm 6.82 \times 10^{3}$ \\
\hline 13. & Golden Trevally & 05 & $5.42 \pm 4.69 \times 10^{5}$ & $5.49 \pm 4.42 \times 10^{3}$ \\
\hline 14. & Half-spotted Grouper & 05 & $3.34 \pm 4.33 \times 10^{4}$ & $1.55 \pm 2.50 \times 10^{3}$ \\
\hline 15. & Threadfin Bream & 04 & $2.77 \pm 3.02 \times 10^{4}$ & $1.84 \pm 3.14 \times 10^{3}$ \\
\hline 16. & Dusky Batfish & 04 & $6.27 \pm 1.01 \times 10^{5}$ & $2.85 \pm 3.09 \times 10^{3}$ \\
\hline 17. & Malabar Blood Snapper & 03 & $3.70 \pm 4.00 \times 10^{4}$ & $4.17 \pm 6.78 \times 10^{3}$ \\
\hline 18. & Eastern Little Tuna & 03 & $8.40 \pm 7.68 \times 10^{4}$ & $9.30 \pm 1.08 \times 10^{2}$ \\
\hline 19. & Black-banded Trevally & 03 & $1.83 \pm 2.50 \times 10^{5}$ & $8.10 \pm 6.07 \times 10^{2}$ \\
\hline 20. & Haffara Bream & 03 & $8.30 \pm 1.22 \times 10^{5}$ & $1.38 \pm 1.46 \times 10^{3}$ \\
\hline 21. & Longtail Silverbiddy & 03 & $3.34 \pm 4.19 \times 10^{5}$ & $2.50 \pm 1.73 \times 10^{2}$ \\
\hline 22. & Indian Mackerel & 03 & $3.33 \pm 2.49 \times 10^{4}$ & $1.24 \pm 1.53 \times 10^{3}$ \\
\hline 23. & Large-mouth Queenfish & 03 & $4.66 \pm 1.61 \times 10^{4}$ & $4.03 \pm 2.20 \times 10^{2}$ \\
\hline 24. & Bartail Flathead & 02 & $1.05 \pm 2.12 \times 10^{4}$ & $2.05 \pm 7.77 \times 10^{2}$ \\
\hline 25. & Cobia & 02 & $3.50 \pm 2.12 \times 10^{4}$ & $2.25 \pm 1.06 \times 10^{2}$ \\
\hline 26. & Needle Fish & 02 & $4.00 \pm 4.24 \times 10^{4}$ & $9.25 \pm 8.83 \times 10^{2}$ \\
\hline 27. & Pinjalo Snapper & 02 & $6.00 \pm 8.48 \times 10^{4}$ & $1.00 \pm 2.82 \times 10^{4}$ \\
\hline 28. & Hardnose Shark & 02 & $7.75 \pm 5.86 \times 10^{4}$ & $4.30 \pm 4.66 \times 10^{2}$ \\
\hline 29. & Greater Lizardfish & 02 & $2.32 \pm 2.01 \times 10^{5}$ & $6.39 \pm 8.24 \times 10^{3}$ \\
\hline 30. & Ribbon Fish & 02 & $2.00 \pm 1.41 \times 10^{4}$ & $1.25 \pm 3.53 \times 10^{2}$ \\
\hline 31. & Largetooth Flounder & 02 & $3.80 \pm 5.65 \times 10^{4}$ & $7.10 \pm 2.96 \times 10^{2}$ \\
\hline 32. & Shrimp Scad & 02 & $8.85 \pm 6.36 \times 10^{4}$ & $8.40 \pm 2.26 \times 10^{2}$ \\
\hline 33. & Prawn & 23 & $3.53 \pm 8.20 \times 10^{6}$ & $1.21 \pm 1.44 \times 10^{4}$ \\
\hline
\end{tabular}




\begin{tabular}{|l|l|l|l|l|}
\hline 34. & Cuttlefish & 22 & $1.10 \pm 2.09 \times 10^{6}$ & $8.32 \pm 1.40 \times 10^{3}$ \\
\hline
\end{tabular}

Table 4:- Bacterial density (CFU g ${ }^{-1}$ ) measured in different seafood samples collected from Wholesale \& Retail markets

\begin{tabular}{|l|l|l|l|}
\hline Place of Sampling & Type of Sample & $\begin{array}{l}\text { TPC } \\
\text { Mean } \pm \text { S.D }\end{array}$ & $\begin{array}{l}\text { Coliforms } \\
\text { Mean } \pm \text { S.D }\end{array}$ \\
\hline \multirow{3}{*}{ Wholesale Market } & Fish & $1.31 \pm 6.36 \times 10^{4}$ & $5.14 \pm 2.40 \times 10^{2}$ \\
\cline { 2 - 4 } & Prawn & $1.47 \pm 1.06 \times 10^{5}$ & $7.36 \pm 9.72 \times 10^{3}$ \\
\cline { 2 - 4 } & Cuttlefish & $8.95 \pm 6.75 \times 10^{3}$ & $1.40 \pm 1.56 \times 10^{2}$ \\
\hline \multirow{3}{*}{ Retail Market } & Fish & $1.74 \pm 4.68 \times 10^{5}$ & $1.69 \pm 3.04 \times 10^{3}$ \\
\cline { 2 - 4 } & Prawn & $3.53 \pm 8.20 \times 10^{6}$ & $1.21 \pm 1.44 \times 10^{4}$ \\
\cline { 2 - 4 } & Cuttlefish & $1.10 \pm 2.09 \times 10^{6}$ & $8.32 \pm 1.40 \times 10^{3}$ \\
\hline
\end{tabular}

\section{References:-}

1. Abolagba, O.J. and Melle, O.O (2008). Chemical composition and keeping qualities of a Scaly Fish Tilapia (Oreochromis niloticus) Smoked with two Energy Sources. African J. Gen. Agric., KLOBEX, 4(2): 113-117.

2. Adebayo-Tayo A.C., Odu, N.N., Michael, M.U. and Okonko, I.O. 2012. Multi-Drug Resistant (MDR) Organisms isolated from Sea-foods in Uyo, South-Southern Nigeria. Nature and Science 10: 61-70.

3. Allen GH, Busch RA, Morton AW. Preliminary bacteriological studies on wastewater-fertilized marine fishponds. Humboldt Bay, California Bay, California. In: Advances in Aquaculture Fishing News Books, Oxford, England 1979; pp. 492-8.

4. Austin B. and Austin DA. (1996) Bacterial pathogens of fish. Journal of Applied Bacteriology, 58 (6): 483-506.

5. Batz MB, Doyle MP, Morris JG Jr, Painter J, Singh R, Tauxe RV et al. Attributing illness to food. Emerging Infectious Diseases, 2005 July. Available from http://www.cdc.gov/ncidod/EID/vol11no07/04-0634.htm

6. Chao, K.K., Chao, C.C. and Chao, W.L.2003.Suitbility of the traditional microbial indicators and their enumerating methods in the assessment of fecal pollution of subtropical freshwater environments. Journal of Microbiology Immunological Infection.36, pp 288-293.

7. Clem, J.D. and S. Garrett, 1968. Sanitation Guidelines for the Breaded-Shrimp Industry. U.S. Dept. of Interior, Fish and Wildlife Service, Bureau of Commercial Fisheries, 308.

8. Clucas, I.J. and Ward, A.R (1996): Post Harvest Fisheries Development. A Guide to Handling, Preservation, Processing and Quality. Chatham Maritime, Kent ME4TB, United Kingdom.pp: 665.

9. Consuelo L. Sousa, José A. Freitas, Lúcia F.H. Lourenço, Eder A. F. Araujo and Maria Regina S. Peixoto Joele,2014. Microbiological contamination of surfaces in fish industry, African Journal of Microbiology Research, Vol. 8(5), pp. 425-431, 29 January, 2014

10. Doyle, M.P. and M.C. Ericson, 2006. Clossing the door on the faecal coliform assay. Microbe., 1: 162-163.

11. Emikpe, B.O., Adebisi, T. and Adedeji, O.B. 2011. Bacteria load on the skin and stomach of Clarias Gariepinus and Oreochromis Niloticus from Ibadan, South West Nigeria: Public health implications. Journal of Microbiology and Biotechnology Research 1: 52-59.

12. Falana, A.A., Determination of profiles of human bacteria pathogens in Nigerian fish and Seafood for Export., 2003. Proceedings of a final Research Coordination meeting held in Mexico city, Mexico., 22-26 July 2002., IAEA-TECDOC-1431

13. FAO: Corporate Document Repository., Quality aspects associated with Seafood.

14. Gonzalez-Fandos, E., 2004. Evaluation of the microbiological safety and sensory quality of rainbow trout (Oncorhynchus mykiss) processed by the sous vide method. Food Microbiol., 21(2): 193-201.

15. Herrera, F.C., J.A. Santos, A. Otero and M.L. Garcia-Lopez, 2006. Occurrence of Food borne pathogenic bacteria in retails prepackage portions of marine fish in Spain. J. Appl. Microbiol., 100(3): 527-36.

16. Hermansen1983.In: Regenstein C.E and Regenstein M.J 1991. Introduction to fish technology. Page 64.Published by Van Nostrand Reinhold, New York.

17. Huss, H.H., Dalgaard, D., Hansen, L., Ladefoged, H., Pedersen, A., and Zittan, L. 1974. The influence in catch handling on the storage life of iced cod and plaice. Journal of Food Technology.9, 213-221.

18. Huss, H.H. 1997. Control of indigenous pathogenic bacterial in seafood. Food Control 8: 91-98.

19. International Commission of Microbiological Specifications for Foods. ICMSF. 1986. Microorganisms in Foods 2- Sampling for Microbilogical analysis: Principles \& Specific applications. Toronto, Ontario, Canada, University of Toronto Press (2nd Edition). 
20. Janice, M. H. and J. S. Lee.1968. Microbiological evaluation of pacific shrimp processing. Applied Microbiology, American Society for Microbiology 18: 2.

21. Jha P, Roy RP, Barat S (2010). Application of sensory and microbial analysis to assess quality of fish in Siliguri city of West Bengal, India. J. Environ. Biol. 31:587-594.

22. Koutsoumanis, K. and G.J. Nychas, 2000. Application of systemic experimental procedure to develop a microbial model for rapid fish shelf life predictions. Int. J. Food Microbiol, 60(2-3): 171-184.

23. Lin Ming-hsien. ICDF Aquaculture Development in the Kingdom of Saudi Arabia, Saudi Arabia Technical Mission, International Cooperation \& Development, pp. 21-24

24. Lyhs, U., 2009. Microbiological Methods. In: Fishery Products Quality, Safety and Authenticity, Rehbein, H. and J. Oehlenschlager (Eds.). Chapter 15, John Wiley and Sons, Inc, New Jersey, ISBN-13: 9781444322675, pp: $318-348$

25. Mahumda, B., Abu, T.A.A., D.M. and P.S. 2010. A comparative microbiological assessment of five types of selected fishes collected from two different markets. Adv. Biol. Res., 4(5): 259-165.

26. Nissen, H.; Maugesten, T. and Lea, P. (2001):Survival and growth of Escherichia coli 0157:H7, Yersinia enterocolitica and Salmonella enteritis on decontaminated and untreated meat. Meat Science; 57:291-298.

27. Olayemi AB, Adebayo O, Ojo AO. Microbial flora of six freshwater fish species from Asa River, Ilorin, Nigeria.Rev Biol Trop 1991; 39: 165-7.

28. Onyango, M.D., Sarah Wandili, Rose Kakai, Eliud, N.W., 2009. Isolation of Salmonella and Shigella from fish harvested from the Winam Gulf of Lake Victoria, Kenya., J. Infect. Developing Countries., 3 (2): 99-104

29. Pal, M. 2010. Fish hygiene. MSc Lecture Notes. Addis Ababa University, Faculty of Veterinary Medicine, Debre Zeit, Ethiopia. Pp.1-11.

30. Pal, M. 2012. Food spoilage. Ph.D. Lecture Notes. Addis Ababa University, College of Veterinary Medicine, Debre Zeit, Ethiopia. Pp.1-8.

31. Priyanka Rani Majumdar, Bhakta Supratim Sarker, Swapan Chandra Dey, Debashish Saha, Ripon Kumar Adhikary and Shuvagato Mondal., 2014. Bacterial Hazards Especially Pathogenic to Human in Consumable Marine fishes of Noakhali Sadar, Bangladesh., American Journal of Food Technology

32. Reza, M. S., et al. 2009. Shelf life of several marine fish species of Bangladesh during ice storage. Int. J. Food Science and Technology 44: 1485-1494.

33. Rhea, F. 2009. Microbiology handbook: Fish and seafood. Leather head Food International Ltd. Surrey, UK.

34. Rombouts FM, Nout R. Food Microbiology and Hygiene. Encyclopedia of Human Biology Academic Press, 1994; III: 661-665.

35. Salim, G. M.2005. A Study on the bacteriology of smoked thai Pangas (Pangasius hypophthylmus). M. Sc. Thesis, Bangladesh Agricultural University, Mymensingh, Bangladesh.

36. SASO 1571 (GS 1361) Chilled Shrimps.

37. SASO 708 (GS 380) Chilled Fish.

38. SASO 1556 (GS 1016) Microbiological Criteria for Foodstuffs-Part 1

39. Shankar Chandra Mandalm, M. Hassan, M.S Rhman, M.H Manik, Zahid H.M and M.D Sirajul Islam (2009): World Journal of fish and Marine science (3): 160-166. ISSN 1992- 0083

40. Temelli S, Dokuzlu C, Sen MKC (2006). Determination of microbiological contamination sources during frozen snail meat processing stages. Food Control 17:22-29.

41. Thabit Zahran Salim Al- Abdessalam (1995). Marine Species of the Sultanate of Oman, Marine Science and Fisheries Centre, Ministry of Agriculture and Fisheries, Oman.

42. USFDA BAM (Online), http://www.fda.gov/Food/FoodScienceResearch/LaboratoryMethods/ucm2006949.htm

43. Wajeeha S. Al-Baharna (1986). Fishes of Bahrain, Ministry of Commerce and Agriculture, Directorate of Fisheries, Bahrain.

44. Wekell, M.M., Manger, R., Colburn, K., Adams, A and Hill, W., 1994. Microbiological Quality of Seafoods: Viruses, Bacteria and Parasites., Shahidi F and Botta, J.R., Eds., Seafoods Chemistry, Processing technology and Quality, Chapman \& Hall, Glasgow., pp 220-232

45. Wogu, M.D., Maduakol, M., 2010. Evaluation of Microbial Spoilage of some aqua cultured fresh fish in Benin city, Nigeria., Ethiopian J. Environ. Studies Manag., 3 (36): 18-22

46. Yagoub, S.O. and T.M. Ahmed, 2004. Pathogenic Microorganisms in fresh water Samples collected from Khartoum central market. Sudan J. Vet. Sci. Anim. Husbandry, 43(1-2): 32-37.

47. Yagoub, S.O. 2009. Isolation of Enterobacteria and Pseudomonas species from raw fish sold in fish market in Khartoum State. Journal of 27.Bacteriological Research. 1(7):85-88. 